\title{
A temperature-dependent physiologically based model for the invasive apple snail Pomacea canaliculata
}

\author{
Gianni Gilioli $^{1}$ • Sara Pasquali ${ }^{2}$ Pablo R. Martín ${ }^{3} \cdot$ Nils Carlsson $^{4} \cdot$ Luigi Mariani $^{5,6}$
}

Received: 10 October 2016/Revised: 4 May 2017 / Accepted: 5 May 2017/Published online: 24 May 2017

(C) ISB 2017

\begin{abstract}
In order to set priorities in management of costly and ecosystem-damaging species, policymakers and managers need accurate predictions not only about where a specific invader may establish but also about its potential abundance at different geographical scales. This is because density or biomass per unit area of an invasive species is a key predictor of the magnitude of environmental and economic impact in the invaded habitat. Here, we present a physiologically based demographic model describing and explaining the population dynamics of a widespread freshwater invader, the golden apple snail Pomacea canaliculata, which is causing severe environmental and economic impacts in invaded wetlands and rice fields in Southeastern Asia and has also been introduced to North America and Europe. The model is based on bio-demographic functions for mortality, development and fecundity rates that are driven by water temperature for the aquatic stages (juveniles and adults) and by air temperature for
\end{abstract}

Electronic supplementary material The online version of this article (doi:10.1007/s00484-017-1376-3) contains supplementary material, which is available to authorized users.

Sara Pasquali

sara.pasquali@mi.imati.cnr.it

1 DMMT, University of Brescia, Viale Europa 11, 25123 Brescia, Italy

2 CNR-IMATI, Via A. Corti 12, 20133 Milan, Italy

3 INBIOSUR (UNS-CONICET), Universidad Nacional del Sur, San Juan 670, Bahía Blanca, Argentina

4 Environmental Department, The County Administrative Board, 205 1 Malmo, Sweden

5 Lombard Museum of Agricultural History, Via Celoria, 2, 20133 Milan, Italy

6 DiSAA, Università degli Studi di Milano, Via Celoria 2, 20133 Milan, Italy the aerial egg masses. Our model has been validated against data on the current distribution in South America and Japan, and produced consistent and realistic patterns of reproduction, growth, maturation and mortality under different scenarios in accordance to what is known from real $P$. canaliculata populations in different regions and climates. The model further shows that $P$. canaliculata will use two different reproductive strategies (semelparity and iteroparity) within the potential area of establishment, a plasticity that may explain the high invasiveness of this species across a wide range of habitats with different climates. Our results also suggest that densities, and thus the magnitude of environmental and agricultural damage, will be largely different in locations with distinct climatic regimes within the potential area of establishment. We suggest that physiologically based demographic modelling of invasive species will become a valuable tool for invasive species managers.

Keywords Population dynamics · Physiologically based demographic model $\cdot$ Apple snail Pomacea canaliculata $\cdot$ Life cycle

\section{Introduction}

Costly and ecosystem-damaging species invasions are so commonplace today that policymakers and managers may have to focus their efforts on the most damaging ones. In order to do this, we need to improve our ability to forecast both the potential spatial area that could be invaded by a certain species and where, within this potential area, the negative effects from the invader are likely to be most pronounced. A method often used is climate matching where the temperatures in the native range of a species are used to forecast potential spread and establishment in non-native areas. A suitable climate alone is 
not enough for an invader to survive and thrive, however. When both the climate match and the ecological niche characteristics of a species in the native, natural range are considered together, as in ecological niche modelling, the spatial course that an invasion may take is possible to forecast with relatively high confidence (Peterson 2003; Byers et al. 2013).

The combination of climatic and habitat variables is a powerful way to model the distributions of invasive species but does not provide us with information about the variability and adaptability of life history traits, their consequences on population dynamics, nor on how the density of the invader across different geographical scales is distributed. If this information was available, management efforts could be concentrated to "hot spots" (i.e., high-density areas) where the negative effects of an invader are likely to be high, and less effort could be spent in areas where the negative effects are low. In order to achieve such focused and cost-efficient management strategies, we need to increase our ability to forecast the spatio-temporal pattern of population dynamics of the same invader within the potential, invasible geographical range (Pasquali et al. 2015).

In this study, we use the highly invasive snail Pomacea canaliculata as a case study illustrating the potentiality of the physiologically based demographic modelling approach to describe and forecast population dynamics of an invasive species at different locations. The genus Pomacea includes a number of large freshwater snail species that are native to South America and one species that is native to the southern USA (Hayes et al. 2015). Several of the Pomacea species have characteristics that make them highly invasive such as high fecundity (Keller et al. 2007; Kyle et al. 2013), a polyphagous diet which includes both animal proteins and a wide variety of wild and domesticated aquatic plants (Wong et al. 2010; Burks et al. 2011; Morrison and Hay 2011; Saveanu and Martín 2013) and a tolerance to low oxygen or foul water conditions due to their capacity to breathe air (Seuffert and Martín 2010). All aspects of Pomacea biology, including feeding, growth, sexual activity and egg laying, are highly dependent on temperature (Bae et al. 2015; Albrecht et al. 2005; Estebenet and Martín 2002; Hayes et al. 2015; Seuffert et al. 2010; Seuffert and Martín 2013a, 2016). Among the apple snails, only $P$. canaliculata has been listed among the 100 world worst invaders by the IUCN (Luque et al. 2014) due to its ecological, agricultural and economic impacts (Carlsson et al. 2004; Cowie 2002; Horgan et al. 2014; Nghiem et al. 2013) as well as the risk posed to human health ( $\mathrm{Lv}$ et al. 2011). Recent studies showed that $P$. canaliculata has a higher resistance to both low and high temperatures than other Pomacea species that have also been introduced around the world but have not spread so widely (Matsukura et al. 2015; Mu et al. 2015), and hence, this capacity is probably another key factor in determining its invasiveness.

Potential distribution models have not been extensively used yet in the case of apple snails. Baker (1998) used
CLIMEX, a climate matching model to forecast the invasible areas by $P$. canaliculata in Southeastern Asia and Australia. The same model has been applied recently to evaluate the risk of invasion in the European Union after the detection of Pomacea in the Ebro delta (EFSA PLH Panel, EFSA Panel on Plant Health, 2012). A similar model of climatic matching (Max Ent) was used for another invasive apple snail (Pomacea maculata) in Southeastern USA in combination with regional data on water $\mathrm{pH}$ (Byers et al. 2013). Besides these correlative habitat models, mechanistic niche models incorporating the effect of selected environmental variables on specific components of fitness (Kearney and Porter 2009) have also been used. Halwart et al. (2006) developed an individual-based model to simulate the effects of fallow periods and biocontrol agents on the numbers and dynamics of $P$. canaliculata in rice fields but without consideration of the effects of temperature. A spatially explicit model based on transition matrixes and incorporating biodemographic functions was recently developed to understand the effect of water level and temperature fluctuations on the distribution and abundance of the native apple snail Pomacea paludosa in the Everglades (Darby et al. 2015). In the case of $P$. canaliculata, a mechanistic model for the spread in China, has been developed on the basis of a simple degree-days model for maturity (Zhou et al. 2003), which allows prediction of the number of generations per year at different locations based on air temperatures (Lv et al. 2011). However, at present there has been no attempt to develop distribution models for $P$. canaliculata to predict not only its establishment but also its abundance and biomass at a broad spatial scale. Such models will be an interesting tool to predict apple snail impacts since their damage to rice crops and to wetland diversity and ecological processes are directly related to the biomass of P. canaliculata (Ozawa and Makino 1997; Yusa and Wada 2002; Teo 2003; Carlsson et al. 2004; Fang et al. 2010).

A mechanistic demographic model for $P$. canaliculata represents an opportunity to integrate the quite abundant (Hayes et al. 2015) but still scattered quantitative information relative to the physiology, ecology and behaviour of this highly invasive species. The distribution of $P$. canaliculata is still increasing worldwide, both at low (Ecuador, Horgan et al. 2014), middle (Spain, EFSA PLH Panel, EFSA Panel on Plant Health 2012; Chile, Jackson and Jackson 2009) and high latitude regions (Siberia, Yanygina et al. 2010). The life cycle and life history traits of $P$. canaliculata have proven to be highly plastic and dependent on temperature in laboratory studies (e.g. Albrecht et al. 1999, 2005; Estebenet and Martín 2002; Seuffert et al. 2012; Seuffert and Martín 2013a, 2016), but until now, there has been no way to predict quantitatively its characteristics in field situations. Such a 
model will not only be able to forecast distribution and abundance of this apple snail but may also be used to better understand its life cycle and population dynamics under different climatic scenarios and, therefore, be useful to detect the critical periods for the control or management of its populations.

Although apple snails are aquatic animals, air temperature has been the customary environmental variable in all previous studies. The use of surrogate variables is often acceptable in correlative habitat models (Latzka et al. 2015), but for mechanistic ones, it would be better to use estimations of water temperature at the depths usually occupied by apple snails (less than $0.75 \mathrm{~m}$; Seuffert and Martín 2013b). However, since apple snails from the genus Pomacea deposit their cleidoic egg masses on exposed substrates above the water surface, air temperature should also be considered, since it is relevant for the developmental rate and survival of the embryos (Seuffert et al. 2012; Liu et al. 2011). The simultaneous consideration of air and water temperatures in the model would be useful to forecast apple snail establishment in situations where the expected correlation between the two does not exist, for instance in waterbodies that are under geothermic influence (Collier et al. 2011) or thermally contaminated by energy plants (e.g. Yanygina et al. 2010) and where exotic apple snails have been detected.

Most importantly, however, our aim was to develop a physiologically based demographic model that could forecast not only the establishment of $P$. canaliculata but also its abundance, stage structure and population dynamics on the basis of air and water temperatures at different locations. In this article, we describe the development and parametrization of the model, as well as its calibration using information about populations in the native and invaded range using available information on some locations in Argentina. The calibrated model has been tested considering a location in Japan and a location in China. Then, it has been used to investigate the pattern population dynamics in four different sites characterized by different climatic conditions (Paso de las Piedras - Argentina, LondrinaBrazil, Deltebre - Spain, Hua Hin - Thailand). The analysis of responses of life cycles to temperature has been performed considering average meteorological conditions in the period 20002013 for the four locations. The present model will also help to guide the development of research to estimate the key life history traits and responses to temperature for the development of similar models for other invasive apple snails, notably P. maculata, as well as for other invasive aquatic species.

\section{Material and methods}

\section{Model structure}

The population abundance of the egg, juvenile and adult stages has been calculated using a physiologically based demographic model (PBDM) (Gutierrez 1996). Kolmogorov equations were developed based upon biodemographic and temperature-dependent functions affecting the developmental rate among individuals (Buffoni and Pasquali 2007; Gilioli et al. 2016) (see SM S1). The population dynamics is mechanistically described by biodemographic functions defined at the individual level (development, mortality and fecundity rate functions) and driven by environmental variables, in particular temperature. For the egg stage, air temperature has been considered since eggs are laid above water; for juvenile and adult stages, water temperature, at $-50 \mathrm{~cm}$ (WT-50), has been used because they live in shallow, aquatic habitats. Although not considered here, other environmental abiotic and biotic variables could be introduced in the model.

\section{Data and parameter estimation}

\section{Weather data}

Water temperature is the driving variable for the juvenile and adult apple snail population dynamics considered by the model; air temperature is the driving variable for the egg population dynamics.

Since the objective of our study is the characterization of adaptive responses of life cycles to the different climates, for each location we consider the average temperatures over the period 2000-2013. Hourly values of temperature for all the locations considered in the present paper were simulated with the following algorithm:

1. Daily data of maximum and minimum air temperature (Tx, Tn) for each reference point were rebuilt from the Tx and Tn of the 10 nearest weather stations of NOAA-GSOD dataset (www.ncdc.noaa.gov). To do so, a suitable geo-statistical procedure of weighted averages, with weight inversely proportional to squared distances, was applied to the data of the 10 selected stations previously homogenized to the reference point for height and aspect by the method described in Sect. S2 of the Supplementary Materials. The weighting procedure adopted makes negligible the contribution of more remote stations.

2. Tx and Tn for each reference point were then adopted to simulate hourly air temperatures by means of de Wit's algorithm (de Wit et al. 1978).

3. A reference year with 8760 hourly values was obtained averaging hourly values of the original period 20002013.

4. Hourly water temperatures for the reference year were then obtained by means of a semi-empirical model based on the Fourier equation of heat diffusion (Larnier et al. 2010) applied to hourly air temperatures (see SM S3). 


\section{Life history strategies}

To the best of our knowledge, no studies are available reporting biodemographic functions for $P$. canaliculata. In this paper, development, mortality and fecundity rate functions widely used for other poikilotherm species have been considered and parameters estimated by using information from the literature.
The fecundity rate function is expressed as the number of eggs produced per female per day, and it is supposed to be dependent on the physiological age $x$ (that is the degree of maturation of an individual, here the fraction between number of eggs laid and the potential fecundity) and on the water temperature $T$ (in $\left.{ }^{\circ} \mathrm{C}\right)$

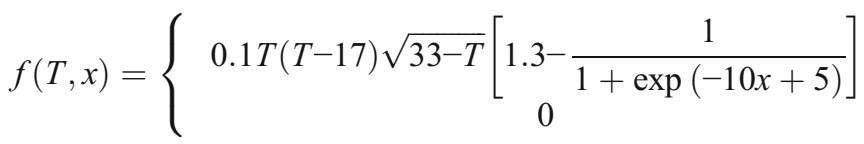

$17 \leq T \leq 33 ; 0 \leq x \leq 1$

otherwise
The water temperature contribution is based on the function proposed in Brière et al. (1999). The physiological age contribution has been defined considering a set of constraints: (i) the maximum fecundity at physiological age zero, (ii) the fecundity monotonically decreases, (iii) the fecundity is always greater than zero and (iv) the total number of eggs laid by a female. Parameters in the fecundity rate function have been estimated based on data for $P$. canaliculata published by Albrecht et al. (1999, 2005), Burela and Martín (2011) and Seuffert and Martín (2016). Water temperatures of 17 and $33{ }^{\circ} \mathrm{C}$ were selected as the lower and upper thresholds of the function since $P$. canaliculata females lay eggs at 20,25 and $30{ }^{\circ} \mathrm{C}$ but not at 15 and $35{ }^{\circ} \mathrm{C}$ (Seuffert and Martín 2016). This function is used for the definition of the adult development rate function.

The temperature-dependent development rate of the egg follows the widely used functional form proposed by Brière et al. (1999) as a general model for the temperature-dependent development rate function of poikilotherm organisms

$$
v(T(t))=\left\{\begin{array}{cc}
0.0001327 T(T-15) \sqrt{35-T} & 15 \leq T \leq 35 \\
0 & \text { otherwise }
\end{array}\right.
$$

where 15 and 35 are the lower and upper temperature (in ${ }^{\circ} \mathrm{C}$ ) development thresholds, respectively. Parameters have been estimated using data from Liu et al. (2012) and Seuffert et al. (2012).

Knowledge on juvenile development rate is still incomplete and further complicated by the fact that the relation between size and age is highly variable and dependent on food availability (Hayes et al. 2015). This makes impossible the use of the most common development rate functions for poikilotherm organisms (Kontodimas et al. 2004). Therefore, we summarized the scattered information available in literature by means of a fifthorder polynomial dependent on temperature only.

$$
\begin{aligned}
v(T(t))= & 0.00000000859 T^{5}-0.00000136 T^{4} \\
& +0.00007085 T^{3}-0.001597 T^{2} \\
& +0.0163 T-0.06187
\end{aligned}
$$

Air temperature (in ${ }^{\circ} \mathrm{C}$ ) has been considered for the egg and water temperature (in ${ }^{\circ} \mathrm{C}$ ) for the juvenile and adult.

The adult development rate function is obtained running an individual-based model (IbM) for a single adult female at a constant temperature taking into account that each adult female lays 4500 eggs on average during her life (Estebenet and Martín 2002). The model presumes that the female dies after she has laid 4500 eggs; consequently, the time needed to lay 4500 eggs is recorded as female adult lifespan. The development rate at a certain constant temperature is obtained by taking the reciprocal of the adult lifespan. The adult development rate is positive in the same interval in which females lay eggs. It is supposed that the adult male development rate is the same as the female development rate and that the proportion of adult males in the population is 50\% (Yusa and Suzuki 2003).

The adult development rate function is obtained by fitting data of the development rates calculated at constant temperatures with the Brière function (Brière et al. 1999)

$$
v(T(t))=\left\{\begin{array}{cc}
0.0000135 T(T-17) \sqrt{33-T} & 17 \leq T \leq 33 \\
0 & \text { otherwise }
\end{array}\right.
$$

The temperature-dependent mortality rate function $m(T)$ is derived from the temperature-dependent finite survival rate $s(T)$ and development rate function $v(T)$ as proposed in Gilioli et al. (2016) and Lanzarone et al. (2017): 
$m(T)=\gamma M+\left\{\begin{array}{clc}-v(T) \ln (s(T)) & \text { for } & T \in\left[T_{\text {inf }}, T_{\text {sup }}\right] \\ -v\left(T_{\text {inf }}\right) \ln \left(s\left(T_{\text {inf }}\right)\left[\frac{\exp \left(T_{\text {inf }}-T\right)}{100}+1\right]\right. & \text { for } & T<T_{\text {inf }} \\ -v\left(T_{\text {sup }}\right) \ln \left(s\left(T_{\text {sup }}\right)\right)\left[0.5\left(T-T_{\text {sup }}\right)^{2}+1\right] & \text { for } & T>T_{\text {sup }}\end{array}\right.$

where $M=\max _{T \in\left[T_{\text {inf }}, T_{\text {sup }}\right]}\{-v(T) \ln (\mathrm{s}(T))\}$ and $\gamma$ is a parameter to be estimated. The mortality rate depends on the development function within the interval where development occurs. The first term $\gamma M$ takes into account abiotic mortality factors different from temperature (e.g. pH, salinity), the effects of which are important under conditions of temperature stress (low temperature during winter period) (Ito 2002).

Combining the few literature data available (Liu et al. 2011) with the opinion of the experts on the shape of the function, eggs' survival function has been described by a generalized extreme value function already used by Son and Lewis (2005) to model survival of a poikilotherm species and, more generally, used in lifetime modelling (Carrasco et al. 2008)

$s(T)=\frac{1}{0.3992} e^{\frac{T-27.7314}{4.3279}} e^{-e \frac{T-27.7314}{4.3279}}$.

As for the development, the air temperature (in ${ }^{\circ} \mathrm{C}$ ) is considered for the eggs and the water temperature (in ${ }^{\circ} \mathrm{C}$ ) for the juveniles and adults. Survival of juveniles and adults is described using a second-order polynomial (Gilioli et al. 2014, 2016; Lanzarone et al. 2017)

$s(T)=p_{1} T^{2}+p_{2} T+p_{3}$

where $p_{1}, p_{2}, p_{3}$ are parameters estimated by fitting data in Pan et al. (2008), Liu et al. (2011) and Seuffert and Martín (2013a). The estimated parameters for juveniles are $p_{1}=-$ $0.00275, p_{2}=0.1045, p_{3}=0$, while those for adults are $p_{1}=-0.002912, p_{2}=0.1077, p_{3}=0$.

Density-dependent mortality appears only when the population density is above a given threshold $\varphi$. This is obtained by increasing the mortality rate $m(T)$ as follows:

$\mu(T)=\left\{\begin{array}{clc}m(T) & \text { if } & N(t) \leq \varphi \\ m(T) \exp [a(N(t)-\varphi)] & \text { if } & N(t)>\varphi\end{array}\right.$

where $N(t)$ is the abundance of juveniles and adults and $\alpha$ and $\varphi$ are parameters introduced to represent the density dependent regulation.

The values of $T_{\text {inf }}, T_{\text {sup }}$ and $\alpha$ for all the three stages are the following:
- Egg: $T_{\text {inf }}=15.0003, T_{\text {sup }}=34.9998, \alpha=0.1$

- Juvenile: $T_{\text {inf }}=11.5, T_{\text {sup }}=36.15, \alpha=0.3$

- Adult: $T_{\mathrm{inf}}=17.05, T_{\mathrm{sup}}=32.96, \alpha=0.2$

The parameter $\varphi$ is taken equal to 10 individuals $/ \mathrm{m}^{2}$ for all the stages to account for the reported effect of high density on the mortality (Tanaka et al. 1999; Yoshida et al. 2013).

\section{Model calibration and validation}

Only a limited number of qualitative (level of abundance) and quantitative (average seasonal population density) datasets on the population dynamics of apple snail are available. This lack of time series data represents a serious hindrance for the application of methods for model parameter estimation and model validation.

The procedure for model calibration proposed is based on the model capability to interpolate the southernmost distribution in Argentina as defined by the information on locations and population dynamics reported in Table 1 (Martín et al. 2001; Seuffert and Martín 2013b; Martín PR, unpublished data). This information concerns the level of population abundance (high or low) and the presence of established local populations. A local population is considered well established if the population persists over time, whereas transient populations that go to extinction within a limited number of years are not considered as established (Gutierrez et al. 2014). Given the limited amount of qualitative data available for the apple snail model calibration, we are restricted to visual comparison of the patterns of population dynamics obtained by simulation and by field reports.

In the group of population classified as "natural" and in the first two sites of the group "introduced", the population density was observed to be high and the species is considered as well established. The edges of the potential distribution were described using the locations with low densities, not spreading populations or having failed introduction to control aquatic weeds. For model calibration purposes, in these locations the population is considered to be at very low density and susceptible to a high risk of local extinction.

For model calibration, changes in fecundity and mortality functions that are less known than development and more sensitive to factors not accounted for in laboratory studies are considered. Considering a density-independent additional mortality component that corresponds to the 
Table 1 P. canaliculata population density in selected locations of South Argentina used for model calibration

\begin{tabular}{|c|c|c|c|c|c|}
\hline Type of population & Location name & Type of dynamics & Longitude & Latitude & Elevation (m a.s.1.) \\
\hline Natural & Pigué stream & High density (established) & $62^{\circ} 28^{\prime} 8.40^{\prime \prime} \mathrm{W}$ & $37^{\circ} 27^{\prime} 1.68^{\prime \prime} \mathrm{S}$ & 230 \\
\hline Natural & Curamalal stream & High density (established) & $62^{\circ} 8^{\prime} 5.78^{\prime \prime} \mathrm{W}$ & $37^{\circ} 14^{\prime} 31.85^{\prime \prime} \mathrm{S}$ & 191 \\
\hline Natural & Corto stream & High density (established) & $62^{\circ} 22^{\prime} 35.81^{\prime \prime} \mathrm{W}$ & $37^{\circ} 25^{\prime} 31.59^{\prime \prime} \mathrm{S}$ & 237 \\
\hline Natural & El Fuerte reservoir & High density (established) & $59^{\circ} 7^{\prime} 50.43^{\prime \prime} \mathrm{W}$ & $37^{\circ} 20^{\prime} 44.23^{\prime \prime} \mathrm{S}$ & 197 \\
\hline Natural & La Manuela pond & High density (established) & $63^{\circ} 1^{\prime} 58.60^{\prime \prime} \mathrm{W}$ & $37^{\circ} 22^{\prime} 33.16^{\prime \prime} \mathrm{S}$ & 187 \\
\hline Introduced & El Durazno stream & High density (established) & $57^{\circ} 49^{\prime} 57.03^{\prime \prime} \mathrm{W}$ & $38^{\circ} 15^{\prime} 45.47^{\prime \prime} \mathrm{S}$ & 10 \\
\hline Introduced & Punta Mogotes artificial pond & High density (established) & $57^{\circ} 32^{\prime} 40.19^{\prime \prime} \mathrm{W}$ & $38^{\circ} 3^{\prime} 53.49^{\prime \prime} \mathrm{S}$ & 14 \\
\hline Introduced & Paso de las Piedras & Low density not spreading & $61^{\circ} 41^{\prime} 43.87^{\prime \prime} \mathrm{W}$ & $38^{\circ} 24^{\prime} 47.46^{\prime \prime} \mathrm{S}$ & 164 \\
\hline Introduced & Los Chilenos lake & Low density not spreading & $62^{\circ} 28^{\prime} 38.82^{\prime \prime} \mathrm{W}$ & $38^{\circ} 1^{\prime} 50.10^{\prime \prime} \mathrm{S}$ & 230 \\
\hline Introduced & Quequén Grande river & Low density not spreading & $59^{\circ} 7^{\prime} 1.85^{\prime \prime} \mathrm{W}$ & $38^{\circ} 11^{\prime} 53.62^{\prime \prime} \mathrm{S}$ & 82 \\
\hline Introduced & CORFO drainage channels & Failed massive introduction & $62^{\circ} 24^{\prime} 58.63^{\prime \prime} \mathrm{W}$ & $39^{\circ} 34^{\prime} 57.24^{\prime \prime} \mathrm{S}$ & 7 \\
\hline
\end{tabular}

Populations are considered well established if the density is high. The locations with low densities, not spreading populations and the site where the massive introduction of apple snail failed are considered at the edge of the potential distribution

term $\gamma M$ in Eq. (1), a better model performance is obtained. The same is observed modifying the densitydependent mortality rate. Among these two possible changes in the mortality function, only the first has been considered because no data are available on the local resources and presence of competitors or predators which are the variables mainly affecting the density-dependent responses of apple snail population.

The estimated model has been further tested by simulating the northernmost distribution in Japan (Kasumigaura, $36^{\circ} 06^{\prime} 02.44^{\prime \prime} \mathrm{N} / 140^{\circ} 22^{\prime} 38.86^{\prime \prime} \mathrm{E}$ ), where data on population density are available allowing a preliminary validation of the predicted density (Ito 2002). The model has also been tested with data gathered in four small water bodies in Hong Kong by Kwong et al. (2010). For these locations, simulations performed with our model produce abundance estimates lower than those in Kwong et al. (2010) (approximately one half). High abundance observed in Hong Kong can likely be explained in terms of highly favourable conditions (high food availability, lack of competitors or predators) of a very small tropical water body. The model can reach higher abundance increasing the parameter $\varphi$ of the density-dependent mortality functions $\mu(T)$. However, because no data are available for the biotic variables affecting population abundance, our analysis is restricted to the consideration of the influence of meteorological variables only. Then, when data on resources, competitors and predators are not known, we retain the value $\varphi=10$ in agreement with Tanaka et al. (1999) and Yoshida et al. (2013).

In model calibration and validation, the population dynamics model is run starting from an initial condition of one adult per square metre and using the average hourly temperature in the period 2000-2013 (calculated as indicated in the "Weather data" section) for the specific locations to be investigated.

\section{Pattern of population dynamics}

To investigate how species-specific biodemographic traits can guarantee plasticity in the life history and adaptation to the site-specific climatic conditions, we compared (i) the pattern of the life history traits (development periods, survival and reproduction patterns) as they emerge from a single cohort dynamics and (ii) the pattern of population dynamics, in four locations with different climatic conditions. Information on the patterns of life history traits and population dynamics is considered for interpreting the invasion ecology of the apple snail (see Table 2).

The four selected locations and their climate classified accordingly to the Köppen-Geiger climate classification system are as follows:

- $\quad$ Paso de las Piedras (Southern Pampas, Argentina; $38^{\circ} 26^{\prime}$ $\mathrm{S}, 61^{\circ} 46^{\prime} \mathrm{W} ; 160 \mathrm{~m}$ a.s.1.) has a humid subtropical climate (Cfa) characterized by hot humid summers and mild winters. Average annual precipitation is $670 \mathrm{~mm}$, and average annual temperature is $13.2^{\circ} \mathrm{C}$.

- Londrina (Paranà, Brazil; 23 $18^{\prime} \mathrm{S}, 51^{\circ} 09^{\prime} \mathrm{W} ; 550 \mathrm{~m}$ a.s.1.) has a humid subtropical climate (Cfa) characterized by hot humid summers and mild winters. Average annual precipitation is $1623 \mathrm{~mm}$, and average annual temperature is $20.6^{\circ} \mathrm{C}$.

- Deltebre (Ebro Delta, Cataluña, Spain; 40 $43^{\prime} \mathrm{N}, 0^{\circ} 43^{\prime} \mathrm{E}$; $2 \mathrm{~m}$ a.s.1) has a dry summer subtropical climate (Csa) characterized by hot, dry summers and cool, wet winters. Average annual precipitation is $545 \mathrm{~mm}$, and average annual temperature is $17^{\circ} \mathrm{C}$.

- Hua Hin (Thailand; $12^{\circ} 34^{\prime} \mathrm{N}, 99^{\circ} 57^{\prime} \mathrm{E}, 16 \mathrm{~m}$ a.s.1.) has a tropical savanna climate (Aw) characterized by temperatures very warm to hot throughout the year, with only small variations. Average annual precipitation is $955 \mathrm{~mm}$, and average annual temperature is $28.3^{\circ} \mathrm{C}$. 
Table 2 Life history and population dynamic pattern of $P$. canaliculata investigated by the model presented in the "Material and methods" population abundance and physiological age are specified

\begin{tabular}{|c|c|c|c|}
\hline & $\begin{array}{l}\text { Questions on life history and } \\
\text { population dynamics }\end{array}$ & Initial time & $\begin{array}{l}\text { Initial conditions: population abundance } \\
\text { Physiological age }\end{array}$ \\
\hline$Q 1$ & Developmental pattern & $\begin{array}{l}\text { Deltebre: May } 1 \text { Paso de las } \\
\text { Piedras: Nov. } 1 \\
\text { Londrina: Jan. } 1 \text { and July } 1 \\
\text { Hua Hin: Jan. } 1 \text { and July } 1\end{array}$ & Cohort of 100 eggs of physiological age 0 \\
\hline$Q 2$ & $\begin{array}{l}\text { Possibility to complete the cycle in a year } \\
\text { (development of a cohort at the beginning } \\
\text { of the warm season) }\end{array}$ & $\begin{array}{l}\text { Deltebre: March } 8 \\
\text { Paso de las Piedras: August } 10\end{array}$ & Cohort of 100 eggs of physiological age 0 \\
\hline$Q 3$ & Survival pattern & $\begin{array}{l}\text { Deltebre: May } 1 \\
\text { Paso de las Piedras: Nov. } 1 \\
\text { Londrina: Jan. } 1 \text { and July } 1 \\
\text { Hua Hin: Jan. } 1 \text { and July } 1\end{array}$ & Cohort of 100 eggs of physiological age 0 \\
\hline$Q 4$ & Winter survival & $\begin{array}{l}\text { Deltebre: Nov. } 24 \\
\text { Paso de las Piedras: May } 29\end{array}$ & $\begin{array}{l}\text { Three initial conditions: cohort of } 10 \text { eggs, } 10 \\
\text { juveniles or } 10 \text { adults of physiological age } 0\end{array}$ \\
\hline$Q 5$ & Pattern of reproduction (fecundity rate) & $\begin{array}{l}\text { Deltebre: May 1, Sept. } 1 \\
\text { Paso de las Piedras: Nov. 1, March } 1 \\
\text { Londrina: Jan. } 1 \text { and July } 1 \\
\text { Hua Hin: Jan. } 1 \text { and July } 1\end{array}$ & One female of physiological age 0 \\
\hline Q6 & Pattern of the population dynamics & $\begin{array}{l}\text { Deltebre: July } 1 \\
\text { Paso de las Piedras: January } 1 \\
\text { Londrina: January } 1 \\
\text { Hua Hin: January } 1\end{array}$ & One adult of physiological age 0 \\
\hline
\end{tabular}

\section{The design of simulation experiments}

In Table 2, the relevant questions considered in the simulation are summarized to better understand the life history and the pattern of population dynamics of $P$. canaliculata. For each question, a single-cohort population dynamics is considered specifying the initial time (the day in the year), the initial conditions in terms of population abundance and physiological age and the demographic processes activated in the model (development, mortality and fecundity). Simulation outputs are provided as Supplementary Material (SM S4).

\section{Results}

\section{Model calibration and validation}

Model simulations not considering the additional mortality term $\gamma$ and based on the parameters presented in the "Data and parameter estimation" section revealed an overestimation of the capability of establishment and difficulties in interpolating data concerning the southernmost locations of natural and introduced and established populations in Argentina (Table 1). The consideration of an additional temperatureand density-independent mortality component was found to improve the model fit of data from Argentina.

The estimated values of $\gamma$ drove populations at Los Chilenos and Quequén to a very low density range between section in different locations characterized by different climate. For each question $Q$, the initial time and the initial conditions in terms of 
Fig. 1 Population dynamics of the apple snail, for the three biological stages considered by the models, at locations Los Chilenos Lake ( $38^{\circ} 1^{\prime} 50.10^{\prime \prime}$ $\left.\mathrm{S} / 62^{\circ} 28^{\prime} 38.82^{\prime \prime} \mathrm{W}\right)$, Quequén Grande River ( $38^{\circ} 11^{\prime} 53.62^{\prime \prime}$ $\left.\mathrm{S} / 59^{\circ} 7^{\prime} 1.85^{\prime \prime} \mathrm{W}\right)$, Paso de las Piedras Reservoir (38 $24^{\circ} 47.46^{\prime \prime}$ $\left.\mathrm{S} / 61^{\circ} 41^{\prime} 43.87^{\prime \prime} \mathrm{W}\right)$ in Argentina, and Kasumigaura ( $36^{\circ} 06^{\prime} 02.44^{\prime \prime}$ $\mathrm{N} / 140^{\circ} 22^{\prime} 38.86^{\prime \prime} \mathrm{E}$ ) in Japan.

Los Chilenos and Quequén dynamics are obtained using the parameters $\gamma=1.9$ (model PM1.9) and $\gamma=1.95$ (model PM1.95) and an initial condition of one adult at 1st January. Paso del las Piedras dynamics are obtained using the parameters $\gamma=$ 2 (model PM2) and $\gamma=2.05$ (model PM2.05) and an initial condition of one adult at $1 \mathrm{st}$ November. Kasumigaura dynamics are obtained using the model PM2 with an initial condition of one adult at $1 \mathrm{st}$ January
Los Chilenos PM1.9
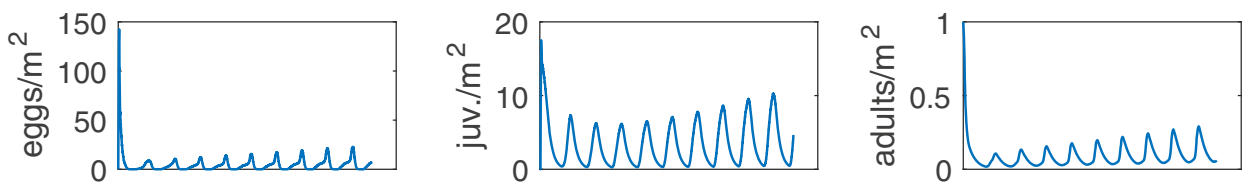

Los Chilenos PM1.95
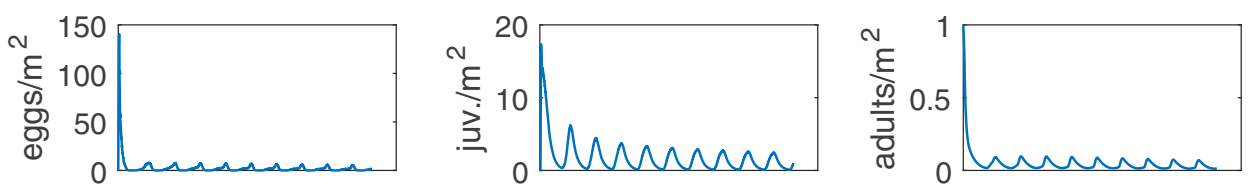

Quequen PM1.9
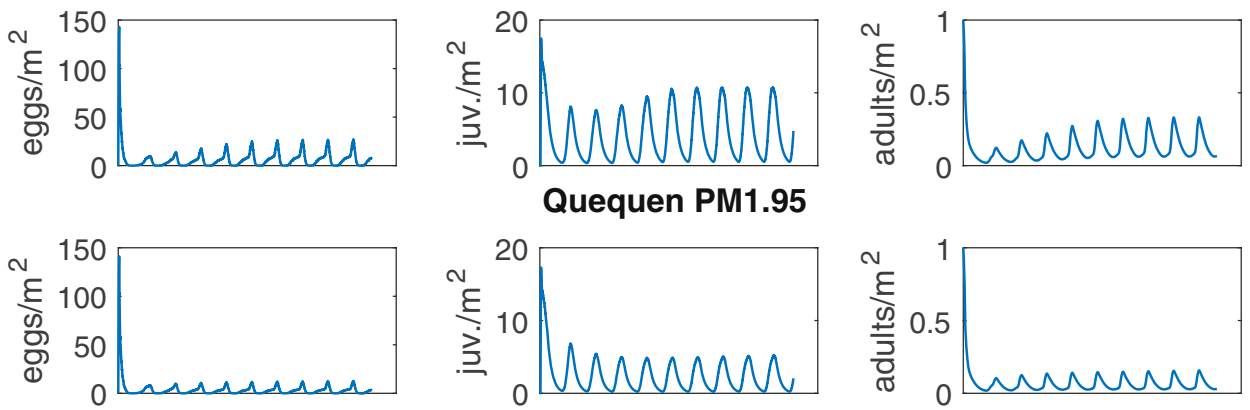

Paso de las Piedras PM2
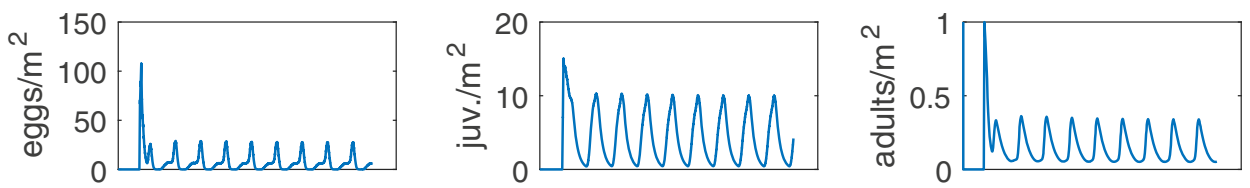

Paso de las Piedras PM2.05
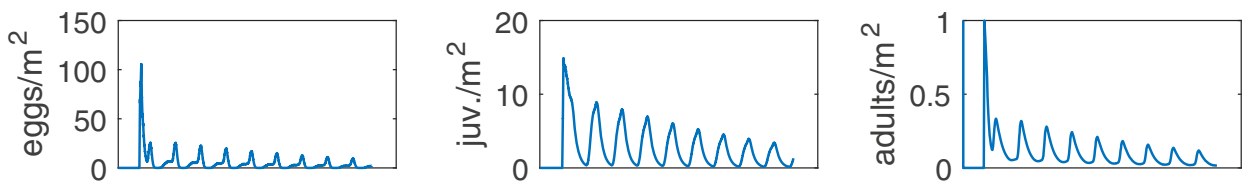

\section{Kasamigaura PM2}
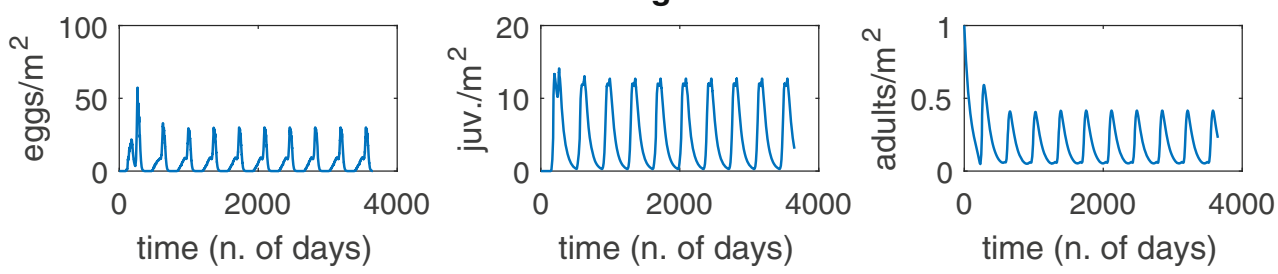

four locations. To perform this analysis, mortality and reproduction are not taken into account. The time needed for the snails to begin to mature, including the time needed for the eggs to hatch, was around 3 months for the temperate locations and around 2 months in Hua Hin and 3 months in Londrina for the tropical locations (Fig. S2). However, at Paso de las Piedras, the peak in the number of mature snails occurs after more than a year, indicating that some snails will need to overwinter before attaining maturity. The potential duration of the life cycle (i.e. without taking mortality into account) is longer than 2 years (28 months) at Paso de las Piedras and 19 months at Deltebre. The life cycle duration at the tropical locations was shorter, 11 months at Londrina and 14 months at Hua Hin.

$Q 2$. We investigated the possibility that snails born at the beginning of the reproductive season attain sexual maturity within that same reproductive season or, alternatively, we establish when the reproduction appears. This aspect is very important because it can have strong effects on population growth rate. To perform this analysis, mortality and 
reproduction are not taken into account. The juveniles from the first eggs to hatch in a reproductive season begin to become adults after approximately 100 days at both temperate locations (Fig. S3), so they are able to lay eggs before water temperatures drop at the end of summer or early fall. However, when fecundity and mortality are considered, the reproductive output of these snails is low, especially at Paso de las Piedras (Fig. S4).

Q3. We investigate the maximum extension of the whole lifespan in seasonal temperate areas and in tropical areas. To perform this analysis, development and mortality are taken into account, but not fecundity. The duration of the life cycle is considerably shortened when mortality is considered (Fig. S5). Almost no adults survive more than 500 days in temperate locations. The duration at the tropical locations was shorter in the tropical locations (less than 7 months at Hua Hin and 10 months at Londrina).

Q4. Simulations of cohorts of different biological stages are performed to analyse the survival pattern at the end of the winter. To perform this analysis, development and mortality are taken into account, but not fecundity. According to the simulation, eggs overwinter at the two temperate locations only at extremely low abundance and can be considered more than zero only for numerical reasons. The same is true for the juveniles and adults at the following spring reported in SM Fig. S6. At both Deltebre and Paso de las Piedras, less than $10 \%$ of juveniles recruited at the end of autumn survive through the winter but they soon mature when temperature rises in spring and summer (Fig. S7). At both locations, around $30 \%$ of the newly mature snails survive to the next spring (Fig. S8).

Q5. We investigated the temporal pattern of egg laying (i.e. the time variation of the fecundity rate) relative to the period of the year in which reproduction starts in a given population/ place. To perform this analysis, development and fecundity are taken into account, but not mortality. The individual reproductive periods predicted by the model lasted around 200 days at temperate locations for females maturing early in the warm season (Fig. S9); at both locations, the females are able to reproduce and lay eggs in the second summer, but the fecundity was very much lower, especially at Deltebre. However, the numerical significance of the reproductive output in the second period is much greater for females starting to reproduce late in the summer (Fig. S10). At the tropical locations, the reproductive period varied between 150 and 350 days depending on the starting date, but there was always a single reproductive period (i.e. egg laying is not interrupted by low temperatures).

Q6. The pattern of population dynamics is investigated as a function of the climate characterizing the four locations. To perform this analysis, both mortality and fecundity are taken into account. Starting with low adult densities $\left(0.1\right.$ adult $\left./ \mathrm{m}^{2}\right)$, the model reaches a steady state in less than 2 years at tropical locations and in almost 3 years at temperate ones (Fig. S11); starting the simulations with high adult densities $\left(1\right.$ adult $\left./ \mathrm{m}^{2}\right)$ only shortens the time needed for the steady state in temperate populations (not shown). At the temperate locations, egg laying is highly seasonal; the population number is also highly variable during the year for the juvenile and adult stages (the maximum population density is $20-30$ times the minimum for the juveniles and 5-10 times for the adults). According to the model, egg laying is almost continuous during the year at the two tropical locations, with minor peaks or drops. In tropical climate, densities of juveniles and adults show little variation during the year as compared to temperate locations (difference of less than $40 \%$ between minimum and maximum population densities). At both tropical and temperate areas, there are important differences between locations. For instance, the population at the lower latitude location (Hua Hin) showed lower mean densities of eggs and adults and also a synchronous decrease in the density of all three life stages during late summer.

\section{Discussion and conclusions}

A physiologically based demographic model describing the dynamics of $P$. canaliculata has been developed using literature data on development, mortality and fecundity rate functions. The model has been calibrated to reproduce the distribution in some locations in Argentina where the level of abundance is known. Density- and temperature-independent mortality rate functions were added to better estimate the level of abundance in the locations considered. The model was validated with data on population density from two locations, one in Japan and one in China. A good approximation of sampling data was obtained for Kasumigaura (Japan), while an underestimation of density in Hong Kong was observed. In the latter, the fit can be improved by modifying the densitydependent mortality. In this way, the model is able to account for the consequences of the availability of resources on local population dynamics.

The model allows prediction of the pattern of the life history and the population dynamics, providing elements to interpret the invasion ecology of these apple snails. The simulations showed that even at the highest latitude, the snail populations in temperate regions are able to attain maturity in the reproductive season in which they are born. However, the proportion of snails that mature in the same season in which they were born and their reproductive output before their first reproductive season ends was quite lower in Paso de las Piedras ( $38^{\circ} 24^{\prime} \mathrm{S}, 164 \mathrm{~m}$ a.s.l.) relative to Deltebre $\left(40^{\circ} 43^{\prime}\right.$ $\mathrm{N}, 2 \mathrm{~m}$ a.s.1.), which may explain in part the higher population densities predicted for the latter. At the temperate locations, no eggs overwinter and the adult stage had the highest survival during winter although juveniles also contribute to the next reproductive season, which is in accord with observations in 
temperate locations in paddy fields in the invaded range (Japan) (Ito 2002; Yoshida et al. 2009).

The extended lifespan duration under temperate thermal regimes relative to tropical ones predicted by the model agrees with the results from laboratory experiments (Estebenet and Cazzaniga 1992; Estebenet and Martín 2002). However, the predicted age at maturity varied less with geographical location and climate than potential life cycle duration. Apparently, temperate summers, even at the extreme latitude populations, allow maturation almost as fast as under tropical climates, perhaps due to the detrimental effects of temperatures above $30{ }^{\circ} \mathrm{C}$ in the latter (Seuffert and Martín 2010, 2016; Seuffert et al. 2010). On the other hand, the potential lifespan (without taking mortality into account) in temperate locations is extended up to 28 months. Sublethal cold periods may prolong the life cycle (Estebenet and Martín 2002), probably due to the deep lethargy of the snails during winter (Seuffert et al. 2010). A lower age at maturity and hence a higher number of complete generations per year have been considered a cause for a higher biotic potential of $P$. canaliculata and invasiveness in tropical areas (Martín et al. 2001). According to the simulations, although periods of low temperature prolong the lifespan due to the slowing of developmental rates of all stages, when temperature-related mortality is incorporated, the lifespan is considerably shortened (less than 17 months in temperate locations). This estimation is considerably shorter than the one obtained by Estebenet and Cazzaniga (1992) for laboratory cohorts under room conditions (9$29^{\circ} \mathrm{C}$ ). This difference is probably due to the high mortality rates that our model assumes when water temperature drops below $5{ }^{\circ} \mathrm{C}$. Winter mortality has been considered a crucial factor in the dynamics of $P$. canaliculata populations in Japan (Tanaka et al. 1999; Yoshida et al. 2009).

The model showed the change from semelparous to iteroparous populations predicted by laboratory studies when moving from tropical to temperate locations (Estebenet and Cazzaniga 1992, 1993; Estebenet and Martín 2002). However, the number of reproductive seasons predicted by the model for temperate locations (two) was lower than the three to four predicted by the laboratory studies (Estebenet and Cazzaniga 1993; Estebenet and Martín 2002). The duration of the reproductive seasons predicted by the model for temperate locations (around 200 days) was somewhat longer than those observed at the southernmost populations in Argentina (150 days; Estebenet and Martín 2002; Martín and Estebenet 2002; Martin PR, unpub. res.). This is probably due to behavioural effects not considered in the model: $P$. canaliculata snails show some degree of delay in getting active when water temperature fluctuates daily around $15{ }^{\circ} \mathrm{C}$ (Seuffert et al. 2010), and this would delay the beginning of the reproductive season in late spring.

Our model predicts that when establishment of invading apple snails is possible, their populations rapidly attain its maximum densities. The generation time and the intrinsic rate of increase estimated through laboratory experiments suggest that population increase may be high, especially under tropical conditions (Estebenet and Cazzaniga 1993; Seuffert and Martín 2016). Field studies tracking densities during apple snail invasion are not available, but the sudden appearance of highdensity populations indicates that the increase is often fast (34 years; Horgan et al. 2014), even in temperate regions (e.g. López Soriano et al. 2009). These predictions are also consistent with theoretical models that suggest that $P$. canaliculata populations may not show mate search-related Allee effects (Jerde et al. 2009) due to the female's capacity to store viable sperm and to express their full fecundity potential after just one copulation (Burela and Martín 2011).

The stage structure of the tropical populations is less variable during the year than that of temperate ones, but the greater difference between the predictions of the model for temperate and tropical locations is the higher mean density of juveniles during the year (2 to 6 vs. 12 juveniles $/ \mathrm{m}^{2}$, respectively). Other things being equal, the higher densities of juveniles and hatchlings throughout the year and their higher specific consumption rates (Carlsson and Brönmark 2006; Tamburi and Martín 2009; Saveanu and Martín 2013, 2015) may explain the great impact of $P$. canaliculata on floating and submerged vegetation in tropical regions (Carlsson et al. 2004).

The model shows that in tropical areas the reproductive period is continuous and densities and activity of both juvenile and adult snails are high all the year round. However, at the lowest latitude location (Hua Hin, $12^{\circ} \mathrm{S}$ ) the densities are lower than at Londrina $\left(23^{\circ} \mathrm{S}\right)$ and also the three stages reach a minimum simultaneously (especially low for eggs and adults) in coincidence with the month of maximum mean temperatures (April, $34.9^{\circ} \mathrm{C}$ ). This is probably due to the negative effects of temperatures above $30^{\circ} \mathrm{C}$ on survivorship, developmental rate and fecundity and would be the best temporal window to attack and further reduce the apple snail populations from the equatorial belt. The negative effects of temperature during very warm summers probably will be higher than predicted at waterbodies like rice fields that are shallower than the ideal wetlands of our model ( $0.5 \mathrm{~m}$ deep).

On the whole, the model produced consistent and realistic patterns of reproduction, growth, maturation and mortality of the apple snails. The model predictions under different scenarios are qualitatively in accordance with what is known from studied populations in different regions or climates and to what has been predicted on experimental or theoretical grounds. Although more rigorous tests of the validity of the model will require extensive demographic sampling of $P$. canaliculata populations, our model not only provided quantitative estimations of densities of different life stages but also allowed investigation of some key traits of the life cycle that are thought to be relevant in its success as an invader and in its impacts. An invader's impact is correlated with its 
abundance (Ricciardi 2003), and the fact that the model is able to predict the snail density and its temporal dynamics makes it a suitable tool for estimating the density-dependent impact on native biodiversity and ecosystem services particularly in tropical areas (Carlsson et al. 2004), as well as on local economies like the damage to rice crops in Southeast Asia (Ozawa and Makino 1997; Yusa and Wada 2002; Teo 2003).

A physiologically based demographic model like ours is helpful to project the potential area of establishment for $P$. canaliculata and other invasive species. We may then use the model to predict the potential densities within the invadible range at suitable spatial resolution (as done in Gilioli et al. 2014). This in turn allows us to roughly translate the potential densities into an estimated impact on biodiversity, ecosystem services and local economies (for example agriculture, forestry or fisheries) in different areas. At regional or larger spatial scale, our model may aid policymakers and invasive species managers to optimize both prevention of establishment and management (or even eradication) of established P. canaliculata populations, or populations of other invasive species (Castillo and Casal 2006; Smith 2006). Bans or quarantines are not necessary where a species cannot establish and management efforts could be omitted in areas where snail density would not attain densities that result in detectable crop damage, detrimental impact on biodiversity or ecosystem services. In the model, temperature is the driving environmental factor explaining stage-specific development, mortality and adult fecundity. However, it is widely known that other environmental variables, especially food availability, affect the population density in apple snails. The model considers a density-dependent component that allows for inclusion of the influence of local resource availability on the population abundance. This may improve the site-specific model prediction of snail abundance. Such high-resolution spatial analysis can be used to support decision-making for pest population management.

The management of already established populations will be most time- and cost-effective when we have identified the period in which the snail population is most vulnerable to control measures. The exploration of pest management scenario can be easily performed by model simulation changing some mortality factors during part of the simulation. Our model may be used to incorporate the effect of control measures (destruction of egg masses, mechanical control of adults, etc.) and their possible combination in different periods of the year in order to determine when they are most effective in different climates.

Our results indicate that in temperate climates no eggs would overwinter. This allows managers to concentrate control efforts entirely on the aquatic stages. The control efforts should be concentrated toward the end of winter when densities are at a minimum but before water temperature rises above $15{ }^{\circ} \mathrm{C}$ and the snails reactivate and, eventually, reproduce.
This temporal window would be optimum for the application of mechanical control measures as handpicking, tillage or water level management, as the snails will not be able to relocate themselves in microhabitats adequate to survive cold damage (Matsukura et al. 2009). Our model can be used to predict this temporal window and its variation according to the different climates and location supporting decision-making in pest management.

\section{References}

AlbrechtEA, Carreno NB, Castro-Vazquez A (1999) A quantitative study of environmental factors influencing the seasonal onset of reproductive behaviour in the South American apple-snail Pomacea canaliculata (Gastropoda: Ampullariidae). J Molluscan Stud 65:241-250

Albrecht EA, Koch E, Carreno NB, Castro-Vazquez A (2005) Control of the seasonal arrest of copulation and spawning in the apple snail Pomacea canaliculata (Prosobranchia: Ampullariidae): differential effects of food availability, water temperature, and day length. Veliger 47:169-174

Bae MJ, Chon TS, Park YS (2015) Modeling behavior control of golden apple snails at different temperatures. Ecol Model 306:86-94

Baker GH (1998) The golden apple snail, Pomacea canaliculata (Lamarck)(Mollusca: Ampullariidae), a potential invader of fresh water habitats in Australia. In: Pest management-future challenges, Vols 1 and 2. Proceedings of the 6th Australian Applied Entomology Research Conference, Brisbane Australia, pp. A21-A26

Brière JF, Pracros P, Le Roux AY, Pierre JS (1999) A novel rate model of temperature-dependent development for arthropods. Environ Entomol 28:22-29

Buffoni G, Pasquali S (2007) Structured population dynamics: continuous size and discontinuous stage structures. J Math Biol 54:555-595

Burela S, Martín PR (2011) Evolutionary and functional significance of lengthy copulations in a promiscuous apple snail, Pomacea canaliculata (Caenogastropoda: Ampullariidae). J Molluscan Stud 77:54-64

Burks RL, Hensley SA, Kyle CH (2011) Quite the appetite: juvenile island apple snails (Pomacea Insularum) survive consuming only exotic invasive plants. J Molluscan Stud 77:423-428

Byers JE, McDowell WG, Dodd SR, Haynie RS, Pintor LM, Wilde SB (2013) Climate and $\mathrm{pH}$ predict the potential range of the invasive apple snail (Pomacea insularum) in the Southeastern United States. PLoS One 8(2):e56812

Carlsson NOL, Bronmark C, Hanson LA (2004) Invading herbivory: the golden apple snail alters ecosystem functioning in Asian wetlands. Ecology 85(6):1575-1580

Carlsson NO, Brönmark C (2006) Size-dependent effects of an invasive herbivorous snail (Pomacea canaliculata) on macrophytes and periphyton in Asian wetlands. Freshw Biol 51(4):695-704

Carrasco JMF, Ortega EMM, Cordeiro GM (2008) A generalized modified Weibull distribution for lifetime modeling. Comput Stat Data Anal 53:450-462

Castillo LV, Casal CMV (2006) Golden apple snail utilization in smallscale aquaculture in the Philippines. In: Joshi RC, Sebastian LS (eds) Global advances in ecology and management of golden apple snails. Philippine Rice Research Institute, Nueva Ecija, pp 475-482

Collier KJ, Demetras NJ, Duggan IC, Johnston TM (2011) Wild record of an apple snail in the Waikato River, Hamilton, New Zealand and their incidence in freshwater aquaria. N Z Nat Sci 36:1-9 
Cowie RH (2002) Apple snails (Ampullariidae) as agricultural pests: their biology, impacts and management. In: Barker GM (ed) Molluscs as crop pests. CABI Publishing, Wallingford, pp 145-192

Darby PC, DeAngelis DL, Romañach SS, Suir K, Bridevaux J (2015) Modeling apple snail population dynamics on the Everglades landscape. Landsc Ecol 30(8):1497-1510

de Wit CT, Goudriaan J, van Laar HH, Penning de Vries FW, Rabbinge R, van Keulen H, Louwerse W, Sibma L, de Jonge C (1978) Simulation of assimilation, respiration and transpiration of crops. Pudoc, Wageningen

EFSA PLH Panel (EFSA Panel on Plant Health) (2012) Scientific opinion on the evaluation of the pest risk analysis on Pomacea insularum, the island apple snail, prepared by the Spanish Ministry of Environment and Rural and Marine Affairs. EFSA J 10(1):2552

Estebenet AL, Cazzaniga NJ (1992) Growth and demography of Pomacea canaliculata (Gastropoda: Ampullariidae) under laboratory conditions. Malacol Rev 25:1-12

Estebenet AL, Cazzaniga NJ (1993) Egg variability and the reproductive strategy of Pomacea canaliculata (Gastropoda: Ampullariidae). Apex 8(4):129-138

Estebenet AL, Martín PR (2002) Pomacea canaliculata (Gastropoda: Ampullariidae): life-history traits and their plasticity. Biocell 26:83-89

Fang L, Wong PK, Lin L, Lan C, Qiu JW (2010) Impact of invasive apple snails in Hong Kong on wetland macrophytes, nutrients, phytoplankton and filamentous algae. Freshw Biol 55(6):1191-1204

Gilioli G, Pasquali S, Marchesini E (2016) A modelling framework for pest population dynamics and management: an application to the grape berry moth. Ecol Model 320:348-357

Gilioli G, Pasquali S, Parisi S, Winter S (2014) Modelling the potential distribution of Bemisia tabaci in Europe in light of the climate change scenario. Pest Manag Sci 70:1611-1623

Gutierrez AP (1996) Applied population ecology: a supply-demand approach. Wiley, New York

Gutierrez AP, Ponti L, Gilioli G (2014) Comments on the concept of ultra-low, cryptic tropical fruit fly populations. Proc R Soc Lond B Biol Sci 281:20132825

Halwart M, Poethke HJ, Kaule G (2006) Golden snail population ecology in rice-fish culture and rice monoculture: a modeling approach. In: Joshi RC, Sebastian LS (eds) Global advances in ecology and management of golden apple snails. Philippine Rice Research Institute, Nueva Ecija, pp 375-392

Hayes KA, Burks RL, Castro-Vazquez A, Darby PC, Heras H, Martín PR, Qiu J-W, Thiengo SC, Vega IA, Wada T, Yusa Y, Burela S, Cadierno MP, Cueto JA, Dellagnola FA, Dreon MS, Frassa MV, Giraud-Billoud M, Godoy MS, Ituarte S, Koch E, Matsukura K, Pasquevich MY, Rodriguez C, Saveanu L, Seuffert ME, Strong EE, Sun J, Tamburi NE, Tiecher MJ, Turner RL, Valentine-Darby PL, Cowie RH (2015) Insights from an integrated view of the biology of apple snails (Caenogastropoda: Ampullariidae). Malacologia 58(1-2):245-302

Horgan FG, Felix MI, Portalanza DE, Sánchez L, Rios WMM, Farah SE, Wither JA, Andrade CI, Espin EB (2014) Responses by farmers to the apple snail invasion of Ecuador's rice fields and attitudes toward predatory snail kites. Crop Prot 62:135-143

Ito J (2002) Environmental factors influencing overwintering success of the golden apple snail, Pomacea canaliculata (Gastropoda: Ampullariidae), in the northernmost population of Japan. Appl Entomol Zool 37:655-661

Jackson D, Jackson D (2009) Registro de Pomacea canaliculata (Lamarck, 1822) (Ampullariidae), molusco exótico para el norte de Chile. Gayana (Concepción) 73(1):40-44

Jerde CL, Bampfylde CJ, Lewis MA (2009) Chance establishment for sexual, semelparous species: overcoming the Allee effect. Am Nat 173(6):734-746

Kearney M, Porter W (2009) Mechanistic niche modelling: combining physiological and spatial data to predict species' ranges. Ecol Lett 12(4):334-350
Keller RP, Drake JM, Lodge DM (2007) Fecundity as a basis for risk assessment of nonindigenous freshwater molluscs. Conserv Biol 21(1):191-200

Kontodimas DC, Eliopoulos PA, Stathas GJ, Economou LP (2004) Comparative temperature-dependent development of Nephus includens (Kirsch) and Nephus bisignatus (Boheman) (Coleoptera: Coccinellidae) preying on Planococcus citri (Risso) (Homoptera: Pseudococcidae): evaluation of a linear and various nonlinear models using specific criteria. Environ Entomol 33(1):1-11

Kyle CH, Plantz AL, Shelton T, Burks RL (2013) Count your eggs before they invade: identifying and quantifying egg clutches of two invasive apple snail species (Pomacea). PLoS One 8(10):e77736

Kwong KL, Dudgeon D, Wong PKW, Qiu JW (2010) Secondary production and diet of an invasive snail in freshwater wetlands: implications for resource utilization and competition. Biol Invasions 12:1153-1164

Lanzarone E, Pasquali S, Gilioli G, Marchesini E (2017) A Bayesian estimation approach for the mortality in a stage-structured demographic model. J Math Biol. doi:10.1007/s00285-017-1099-4

Larnier K, Roux H, Dartus D, Croze O (2010) Water temperature modelling in the Garonne River (France). Knowl Manag Aquat Ecosyst 398:04, $20 \mathrm{pp}$

Latzka AW, Crawford JT, Koblings AS, Caldeira Y, Hilts E, Vander Zanden MJ (2015) Representing calcification in distribution models for aquatic invasive species: surrogates perform as well as $\mathrm{CaCO} 3$ saturation state. Hydrobiologia 746(1):197-208

Liu J, He Y, Tan J, Xu C, Zhong L, Wang Z, Liao Q (2012) Characteristics of Pomacea canaliculata reproduction under natural conditions. Chin J Appl Ecol 23:559-565

Liu Y, Han W, Xian Z (2011) Effect of different temperatures on growth, development and feeding of Pomacea canaliculata. J South Agric 42:901-905

López Soriano J, Quiñonero-Salgado S, Tarruella A (2009) Presencia masiva de Pomacea cf. canaliculata (Lamarck 1822) (Gastropoda: Ampullariidae) en el Delta del Ebro (Cataluña, España) (Massive presence of Pomacea cf. canaliculata in the Ebro Delta). Spira 3:117-121

Luque GM, Bellard C, Bertelsmeier C, Bonnaud E, Genovesi P, Simberloff D, Courchamp F (2014) The 100th of the world's worst invasive alien species. Biol Invasions 16(5):981-985

Lv S, Zhang YI, Steinmann P, Yang GJ, Yang K, Zhou XN, Utzinger J (2011) The emergence of angiostrongyliasis in the People's Republic of China: the interplay between invasive snails, climate change and transmission dynamics. Freshw Biol 56(4):717-734

Martín PR, Estebenet AL (2002) Interpopulation variation in life-history traits of Pomacea canaliculata (Gastropoda: Ampullariidae) in southwestern Buenos Aires Province, Argentina. Malacologia 44:153-163

Martín PR, Estebenet AL, Cazzaniga NJ (2001) Factors affecting the distributionn of Pomacea canaliculata (Gastropoda: Ampullariidae) along its southernmost natural limit. Malacologia 43:13-23

Matsukura K, Izumi Y, Yoshida K, Wada T (2015) Cold tolerance of invasive freshwater snails, Pomacea canaliculata, P. maculata, and their hybrids helps explain their different distributions. Freshw Biol 61(1):80-87

Matsukura K, Tsumuki H, Izumi Y, Wada T (2009) Physiological response to low temperature in the freshwater apple snail, Pomacea canaliculata (Gastropoda: Ampullariidae). J Exp Biol 212(16): 2558-2563

Morrison WE, Hay ME (2011) Herbivore preference for native vs. exotic plants: generalist herbivores from multiple continents prefer exotic plants that are evolutionarily naïve. PLoS One 6(3):e17227

$\mathrm{Mu} \mathrm{H}$, Sun J, Fang L, Luan T, Williams GA, Cheung SG, Wong CKC, Qiu JW (2015) Genetic basis of differential heat resistance between two species of congeneric freshwater snails: insights from quantitative proteomics and base substitution rate analysis. J Proteome Res 14(10):4296-4308 
Nghiem LTP, Soliman T, Yeo DCJ, Tan HTW, Evans TA, Mumford JD, Keller RP, Baker RHA, Corlett RT, Carrasco LR (2013) Economic and environmental impacts of harmful non-indigenous species in Southeast Asia. PLoS One 8(8):e71255

Ozawa A, Makino T (1997) The influence of shell size, snail density and water depth in paddy fields on injury of young rice [Oryza sativa] seedling by the apple snails, Pomacea canaliculata (Lamarck). Bull Shizuoka Agric Exp Stn 42:23-29

Pan Y, Dong S, Yu X (2008) Effects of temperature stress on development, feeding and survival of the apple snail Pomacea canaliculata (Lamarck). Acta Phytophylacica Sin 35(3):224-239

Pasquali S, Gilioli G, Janssen D, Winter S (2015) Optimal strategies for interception, detection, and eradication in plant biosecurity. Risk Anal 35(9):1663-1673

Peterson AT (2003) Predicting the geography of species' invasions via ecological niche modeling. Q Rev Biol 78(4):419-433

Ricciardi A (2003) Predicting the impacts of an introduced species from its invasion history: an empirical approach applied to zebra mussel invasions. Freshw Biol 48(6):972-981

Saveanu L, Martín PR (2013) Pedal surface collecting as an alternative feeding mechanism of the invasive apple snail Pomacea canaliculata (Caenogastropoda: Ampullariidae). J Molluscan Stud 79(1):11-18

Saveanu L, Martín PR (2015) Neuston: a relevant trophic resource for apple snails? Limnologica-Ecol Manag Inland Waters 52:75-82

Seuffert ME, Burela S, Martín PR (2010) Influence of water temperature on the activity of the freshwater snail Pomacea canaliculata (Caenogastropoda: Ampullariidae) at its southernmost limit (southern pampas, Argentina). J Therm Biol 35:77-84

Seuffert ME, Martín PR (2010) Dependence on aerial respiration and its influence on microdistribution in the invasive freshwater snail Pomacea canaliculata (Caenogastropoda, Ampullariidae). Biol Invasions 12(6):1695-1708

Seuffert ME, Martín PR (2013a) Juvenile growth and survival of the apple snail Pomacea canaliculata (Caenogastropoda: Ampullariidae) reared at different constant temperatures. SpringerPlus 2:1-15

Seuffert ME, Martín PR (2013b) Distribution of the apple snail Pomacea canaliculata in Pampean streams (Argentina) at different spatial scales. Limnologica-Ecol Manag Inland Waters 43(2):91-99

Seuffert ME, Martín PR (2016) Thermal limits for the establishment and growth of populations of the invasive apple snail Pomacea canaliculata. Biol Invasions. doi:10.1007/s10530-016-1305-0
Seuffert ME, Saveanu L, Martín PR (2012) Threshold temperatures and degree-day estimates for embryonic development of the invasive apple snail Pomacea canaliculata (Caenogastropoda: Ampullariidae). Malacologia 55:209-217

Smith JW (2006) Ampullariidae pathways. In: Joshi RC, Sebastian LS (eds) Global advances in ecology and management of golden apple snails. Philippine Rice Research Institute, Nueva Ecija, pp 113-120

Son Y, Lewis EE (2005) Modelling temperature-dependent development and survival of Otiorhynchus sulcatus (Coleopter: Curculionidae). Agric For Entomol 7:201-209

Tamburi NE, Martín PR (2009) Feeding rates and food conversion efficiencies in the apple snail Pomacea canaliculata (Caenogastropoda: Ampullariidae). Malacologia 51(2):221-232

Tanaka K, Watanabe T, Higuchi H, Miyamoto K, Yusa Y, Kiyonaga T et al (1999) Density-dependent growth and reproduction of the apple snail, Pomacea canaliculata: a density manipulation experiment in a paddy field. Res Popul Ecol 41(3):253-262

Teo SS (2003) Damage potential of the golden apple snail Pomacea canaliculata (Lamarck) in irrigated rice and its control by cultural approaches. Int J Manag 49:49-55

Yanygina LV, Kirillov VV, Zarubina EY (2010) Invasive species in the biocenosis of the cooling reservoir of Belovskaya power plant (Southwest Siberia). Russ J Biol Invasions 1(1):50-54

Yoshida K, Hoshikawa K, Wada T, Yusa Y (2009) Life cycle of the apple snail Pomacea canaliculata (Caenogastropoda: Ampullariidae) inhabiting Japanese paddy fields. Appl Entomol Zool 44(3):465474

Yoshida K, Hoshikawa K, Wada T, Yusa Y (2013) Patterns of density dependence in growth, reproduction and survival in the invasive freshwater snail Pomacea canaliculata in Japanese rice fields. Freshw Biol 58(10):2065-2073

Yusa Y, Suzuki Y (2003) A snail with unbiased population sex ratios but highly biased brood sex ratios. Proceedings of the Royal Society of London. Series B: Biol Sci 270:283-288

Yusa Y, Wada T (2002) Predicting damage to rice by the apple snail Pomacea canaliculata (Ampullariidae) using snail biomass. VII International Congress on Medical and Applied Malacology, Los Banos, Laguna (Philippines), 21-24 Oct 2002

Wong PK, Liang Y, Liu NY, Qiu JW (2010) Palatability of macrophytes to the invasive freshwater snail Pomacea canaliculata: differential effects of multiple plant traits. Freshw Biol 55:2023-2031

Zhou WC, Wu YF, Yang JQ (2003) Viability of Ampullaria snail in China. Fujian J Agric Sci 18(1):25-28 